\title{
HUBUNGAN UMUR POHON DENGAN PRODUKSI DAN MUTU BENIH Acacia mangium Willd., Gmelina arborea Linn., DAN Eucalyptus deglupta Blume
}

\author{
Correlation of Tree Ages with Production and Quality of Acacia mangium Willd, \\ Gmelina arborea Linn. and Eucalyptus deglupta Blume Seeds \\ Dede J. Sudrajat, Nurhasybi dan/and Muhammad Zanzibar \\ Balai Penelitian Teknologi Perbenihan Tanaman Hutan \\ Jl. Pakuan, Ciheuleut, P.O.Box 105 Bogor 16001 \\ Telp./Fax. (0251) 8327768
}

Naskah masuk : 29 November 2010; Naskah diterima : 2 November 2011

\begin{abstract}
This research is aimed to studying trend of correlation between tree ages and potency of seed production and quality of A. mangium, G. arborea and $\mathrm{E}$. deglupta. The seed of A. mangium was collected in Subanjeriji, South Sumatera, while those of G. arborea and E. deglupta were collected in Kenangan, East Kalimantan. The planting spacing of all tree species were $3 \times 3 \mathrm{~m}$. In each level of tree age was selected 10 trees randomly. Seed qualities assessed were weight of 1,000 seeds, germination percentage, and moisture content. The tree ages were regarded as factor and its possible relation with such criteria assessed by completely randomized design and followed with regression analysis. The results revealed that the tree ages of A. mangium did not significantly affect on the seed production and germination percentage, but they significantly affected on the moisture content and weight of 1,000 seed. The trend of seed production of $\mathrm{G}$. arborea increased after 9 years old and reached the maximum on 10 years old then decreased after 13 years old, while the maximum germination capacity was resulted from 11 and 13 years old trees. The tree ages of $\mathrm{E}$. deglupta significantly affected the seed production and germination percentage. The seed production increased on 8 years old trees and achieved the maximum on 9 years old and decreased on the age higher. The seed germination trend of $\mathrm{E}$. deglupta increased by added the tree age. The conclusion indicated that the seed collection can be conducted optimally at the stand ages of 5-12 years old for A. mangium, at the ages of 9-13 years old for $\mathrm{G}$. arborea and at the ages of 8-16 years old for $\mathrm{E}$. deglupta.
\end{abstract}

Keywords: Acacia mangium, Eucalyptus deglupta, Gmelina arborea, seed quality, production, age

\begin{abstract}
ABSTRAK
Penelitian ini bertujuan untuk mempelajari kecenderungan hubungan antara umur pohon dengan potensi produksi dan mutu benih A. mangium, G. Arborea dan E. deglupta. Benih A. mangium diunduh di Subanjeriji, Sumatera Selatan, sedangkan untuk G. arborea and E. deglupta diunduh di Kenangan, Kalimantan Timur. Jarak tanam tegakan pada semua tingkat umur adalah 3 x $3 \mathrm{~m}$. Pada setiap umur di ambil 10 pohon yang dipilih secara acak. Parameter mutu benih adalah berat 1.000 butir, daya berkecambah, dan kadar air. Rancangan yang digunakan adalah rancangan acak lengkap dengan umur pohon sebagai faktor. Analisis regresi dilakukan untuk mengetahui hubungan antara umur pohon dengan produksi dan mutu benih. Hasil penelitian menunjukkan umur pohon $A$. mangium tidak berpengaruh nyata terhadap produksi dan daya berkecambah, namun berpengaruh nyata terhadap kadar air dan berat 1.000 butir benih. Pada G. arborea, umur pohon berpengaruh nyata terhadap produksi dan mutu benih. Kecenderungan produksi benih G. arborea meningkat setelah umur 9 tahun dan mencapai maksimal pada umur 10 tahun kemudian menurun setelah umur 13 tahun, sedangkan daya berkecambah tertingginya terjadi pada umur pohon 11 dan 13 tahun. Untuk E. deglupta, umur pohon berpengaruh terhadap produksi dan daya berkecambah benih. Produksi benih $E$. deglupta meningkat pada umur pohon 8 tahun dan mencapai maksimal pada umur pohon 9 tahun kemudian produksinya menurun lagi sejalan dengan bertambahnya umur pohon. Daya berkecambah benih cenderung meningkat dengan meningkatnya umur pohon. Dengan demikian, pengunduhan benih optimal dapat dilakukan pada tegakan berumur 5-12 tahun untuk A. mangium, umur 9-13 tahun untuk G. arborea, dan umur 8-16 tahun untuk E. deglupta.
\end{abstract}

Kata kunci: Acacia mangium, Eucalyptus deglupta, Gmelina arborea, mutu benih, produksi, umur 


\section{PENDAHULUAN}

Acacia mangium, Gmelina arborea dan Eucalyptus deglupta merupakan jenis-jenis yang banyak dikembangkan dalam pembangunan Hutan Tanaman Industri (HTI) di Indonesia (Apif, 2002; Departemen Kehutanan, 2009). Jenis-jenis tersebut banyak digunakan sebagai bahan baku pulp dan kertas, serta dapat juga digunakan untuk konstruksi bangunan, furnitur, kayu bakar, peti kemas dan lain-lain. Pertumbuhan yang relatif cepat dengan teknik silvikultur yang mudah menyebabkan jenis-jenis ini menjadi jenis prioritas dalam kegiatan penghutanan kembali lahan kritis, padang alang-alang dan daerah terdegradasi lainnya. Di Pulai Jawa, jenisjenis ini juga mulai dibudidayakan sebagai komoditi hutan rakyat.

Ketersediaan benih bermutu, teknologi penanganan benih dan teknik pembibitan harus terus dioptimalkan untuk meningkatkan produktivitas dan keberhasilan pengembangan jenisjenis ini secara berkelanjutan. Sampai saat ini penelitian dan pengembangan mengenai teknologi perbenihan jenis-jenis tersebut telah banyak dilakukan yang meliputi pemrosesan benih, pengujian benih, penyimpanan benih sampai pembibitannya. Namun demikian, teknologi perbenihannya harus terus dikembangkan sejalan dengan permasalahan yang ditemui di lapang. Salah satu informasi yang masih dirasakan kurang adalah gambaran produksi benih dari suatu tegakan (Direktorat Perbenihan Tanaman Hutan, 2008). Produksi benih bervariasi dari tahun ke tahun dan dari satu pohon ke pohon yang lain. Banyak faktor yang mempengaruhi timbulnya variasi ini, antara lain kegagalan pohon untuk berbunga, penyerbukan yang tidak sempurna dan lain-lain (Owens, 1995). Menurut Manan (1983), salah satu aspek yang mempengaruhi produksi benih adalah umur pohon.

Informasi mengenai hubungan antara umur pohon dengan potensi produksi dan mutu benih yang dihasilkannya masih sangat kurang (Espahbodi et al., 2007), sementara informasi ini sangat diperlukan untuk menentukan pada umur berapa suatu tegakan menghasilkan benih dalam jumlah banyak dan mutu yang tinggi. Selain itu informasi ini juga sangat membantu dalam perencanaan pengadaan benih dan penanaman berskala besar (Stubsgaard and Baadsgaard, 1994).

Mutu fisik dan fisiologi benih secara umum merupakan hasil dari kinerja penanganan benih. Namun beberapa parameter seperti berat
1.000 butir dan daya berkecambah kemungkinan ada hubungannya dengan umur pohon induknya. Menurut Manan (1983) dan Ponnusamy (1993), benih dari pohon muda (baru berbuah) sering kurang baik pertumbuhannya. Begitu juga pada pohon yang terlalu tua mempunyai kecenderungan menghasilkan benih yang kurang baik (Pillai, 1994).

Manan (1983) dan Raja et al. (2004) menyatakan bahwa secara umum suatu pohon akan menghasilkan benih dengan jumlah dan mutu yang tinggi pada umur pertengahan. Beberapa penelitian lainnya menunjukkan adanya korelasi antara umur pertengahan (middle age) dengan karakteristik benih, seperti berat 1000 butir, produksi, dan perkecambahan benih pada jenis Pinus echinata (Grayson et al., 2002 dalam Espahbodi et al., 2007) dan Sorbus torminalis (Espahbodi et al., 2007). Artinya pada umur ini pohon dapat memproduksi benih dalam jumlah banyak dengan mutu yang baik (Alrasyid, et al., 1983). Penelitian Mindawati et al. (1991) tentang studi pendugaan produksi buah Eucalyptus deglupta di Balai Teknologi Reboisasi, Benakat, Sumatera Selatan menunjukkan prediksi kapasitas produksi buah E. deglupta dapat didekati melalui persamaan regresi linier $Y$ $=-0,86990,1777_{x 2}+0,408_{x 3}\left(r^{2}=0,66\right)$.

Penelitian ini bertujuan untuk mempelajari pengaruh umur pohon A. mangium, G. arborea dan E. deglupta terhadap potensi dan mutu benih yang dihasilkan, dan kecenderungan hubungan antara umur pohon dengan potensi produksi dan daya berkecambah benih yang dihasilkannya.

\section{BAHAN DAN METODE}

\section{A. Lokasi Penelitian}

Pendugaan potensi produksi dan pengunduhan buah untuk $A$. mangium dilakukan di Subanjeriji, PT. Inhutani V, Sumatera Selatan dan untuk G. arborea dan E. deglupta dilakukan di Kenangan, PT. ITCI Hutani Manunggal, Kalimantan Timur. Pengunduhan buah $G$. arborea dilakukan pada bulan Agustus, buah $A$. mangium dilakukan pada bulan September dan buah E. deglupta dilakukan pada bulan Mei. Pengujian mutu benih dilakukan di Laboratorium Balai Penelitian Teknologi Perbenihan Tanaman Hutan, Bogor.

\section{B. Bahan dan Alat} meliputi :
Bahan dan alat lain yang digunakan 
1. Di lapangan : kompas, haga meter, meteran, peta kerja, tali rafia, golok, timbangan, galah berkait, karung plastik, blangko isian, label pengunduhan.

2. Di laboratorium : timbangan analitik, spatula, meja kemurnian, oven, cawan porselin, kertas merang, desikator.

3. Di rumah kaca : media tanah dan pasir, label, bak kecambah.

\section{Prosedur Kerja}

Penentuan petak uji untuk pemilihan pohon contoh yang akan diunduh buahnya dilakukan berdasarkan data kelas umur pada peta dan register tanaman. Pohon contoh ketiga jenis ini memiliki jarak tanam yang sama, yaitu $3 \times 3$ $\mathrm{m}$. Pemilihan pohon contoh pada setiap jenis dan kelas umur dilakukan secara acak. Jumlah pohon contoh yang dipilih untuk setiap kelas umur adalah 10 pohon. Untuk A. mangium, pemilihan pohon contoh dilakukan pada kelas umur tegakan $5,6,7,9,10,11$, dan 12 tahun sehingga secara keseluruhan berjumlah 70 pohon induk.

Penelitian G. arborea menggunakan kelas umur tegakan 7, 9, 11, 13, 15 dan 17 tahun (60 pohon induk), sedangkan untuk $E$. deglupta, umur tegakan yang diteliti adalah $4,6,8,10,14$, dan 16 tahun (60 pohon induk). Pengunduhan benih $A$. mangium dan $E$. deglupta dilakukan terhadap pohon yang terpilih dengan cara memanjat dan mengumpulkan semua polong dari pohon terpilih. Pengunduhan benih $G$. arborea dilakukan dengan pemanjatan dan pengumpulan buah di sekitar pohon terpilih dengan memperhatikan lebar tajuk dan kemungkinan jatuhnya buah sehingga buah yang dikumpulkan merupakan buah dari pohon terpilih.

Benih hasil pengunduhan dipisahkan per pohon induk dan diberi identitas untuk setiap pohon induk. Benih masak dan benih belum masak pada setiap pohon induk dipisahkan untuk memudahkan pemilihan benih untuk pengujian di laboratorium. Pemilihan benih masak didasarkan pada warna polong atau buah yang dicirikan dengan warna kulit buah hijau kekuningkuningan sampai kuning untuk $G$. arborea, polong yang berwarna coklat untuk $A$. mangium, dan buah yang berwarna hijau kecoklatan untuk E. deglupta.

Ekstraksi polong A. mangium dilakukan dengan menjemur polong di bawah sinar matahari selama 2 hari. Polong yang sudah kering kemudian dimasukan ke dalam karung plastik dan dipukul-pukul hingga hancur. Pemisahan benih dengan kotoran lainnya dilakukan dengan cara penampian. Setelah ditampi, benih dibersihkan dari funikel yang menempel. Benih yang telah bersih dijemur selama 2 hari. Hal yang sama dilakukan pada benih E. deglupta. Selanjutnya, benih $E$. deglupta yang dibersihkan dengan menggunakan ayakan 710 mikrometer dan 300 mikrometer. Benih yang digunakan untuk pengujian adalah benih yang lolos ayakan 710 mikrometer dan tertahan ayakan 300 mikrometer. Ekstraksi benih G. arborea dilakukan dengan menggunakan food processor. Benih yang telah dipisahkan dari kotoran atau bagian yang lain, dibersihkan dengan air yang mengalir sampai tidak ditemukan lagi bagian buah yang menempel. Benih yang telah bersih dijemur selama 1 hari.

Perkiraan produksi benih dilakukan dengan menimbang berat seluruh benih baik yang telah masak maupun yang diperkirakan belum masak dari tiap pohon sampel. Pengujian berat 1.000 butir, kadar air, dan daya berkecambah benih hanya dilakukan pada kelompok benih yang telah masak fisiologis dari masingmasing kelas umur pohon sampel. Berat 1.000 butir benih untuk, penentuan berat 1.000 butir benih hanya dilakukan pada benih $A$. mangium dan G. Arborea, sedangkan benih E. deglupta tidak dilakukan penghitungan berat 1.000 butir mengingat benihnya sangat kecil (benih halus). Penentuan berat 1.000 butir dilakukan dengan cara menghitung berat 100 butir benih dengan 8 kali ulangan. Berat 1.000 butir merupakan berat rata-rata 100 butir benih dikali 10 (Poulsen, 1994; ISTA, 2006; ISTA, 2010). Penentuan kadar air benih dilakukan dengan 4 (empat) ulangan pada setiap kelas umur dan jenis. Setiap ulangan terdiri dari 5 gram benih. Pengukuran kadar air benih dilakukan dengan mengeringkan benih di dalam oven pada suhu $103 \pm 2^{\circ} \mathrm{C}$ selama 18 jam (BTP, 2000; ISTA, 2006; ISTA, 2010). Pengujian perkecambahan benih $A$. mangium dilakukan di laboratorium menggunakan metode UKD (uji di atas kertas) pada media kertas merang dalam germinator, sedangkan benih $G$. arborea dan $E$. deglupta dilakukan di rumah kaca dengan media campuran tanah dan pasir $(1: 1 \mathrm{v} / \mathrm{v})$ yang telah disterilkan. Satu unit percobaan menggunakan 3 ulangan. Setiap ulangan terdiri dari 100 butir benih.

\section{Analisis Data}

Rancangan yang digunakan adalah Rancangan Acak Lengkap (RAL) dengan kelas umur 
pohon sebagai faktornya. A. mangium menggunakan 7 (tujuh) kelas umur $(5,6,7,9,10,11$, dan 12 tahun), $G$. arborea menggunakan 6 (enam) kelas umur (7, 9, 11, 13, 15 dan 17 tahun) dan $E$. deglupta menggunakan 6 (enam) kelas umur $(4,6,8,10,14$, dan 16 tahun). Setiap jenis pohon dilakukan pengulangan sebanyak 10 (sepuluh) kali (pohon sampel) untuk tiap umur. Jika hasil uji $F$ berpengaruh nyata maka dilakukan uji lanjut Duncan. Selanjutnya analisis regresi dilakukan untuk mengetahui model hubungan antara umur pohon dengan produksi dan mutu benih.

\section{HASIL DAN PEMBAHASAN}

\section{A. Hasil}

Umur pohon A. mangium (5 - 12 tahun) tidak berpengaruh nyata terhadap produksi dan daya berkecambah benihnya, tetapi berpengaruh nyata terhadap kadar air dan berat 1.000 butir benihnya. Umur pohon G. arborea (7 - 17 tahun) memberikan pengaruh nyata terhadap semua parameter yang diuji. Untuk E. deglupta (4 - 16 tahun), umur pohon berpengaruh nyata terhadap produksi dan daya berkecambah benih, tetapi tidak berpengaruh terhadap parameter lainnya (Tabel 1).

Tabel(Table) 1. Ringkasan uji $\mathrm{F}$ pengaruh umur terhadap produksi dan mutu benih $A$. mangium, $G$. arborea dan E. deglupta (Summary of F-test of the effect of tree ages on seed production and qualities of A. mangium, G. arborea and E. deglupta)

\begin{tabular}{|c|c|c|c|c|}
\hline No. & Parameter ( Parameters) & $\begin{array}{c}\text { A. mangium } \\
\text { F-hitung } \\
(F-\text {-calc. })\end{array}$ & $\begin{array}{l}\text { G. arborea } \\
\text { F-hitung } \\
(F-c \text {-calc. })\end{array}$ & $\begin{array}{l}\text { E. deglupta } \\
\text { F-hitung } \\
(F \text {-calc. })\end{array}$ \\
\hline 1. & Produksi benih ( seed production ) & $0,31 \mathrm{~ns}$ & $70,49 * *$ & $15,22 * *$ \\
\hline 2. & Kadar air benih (Moisture content) & $44,52 * *$ & $58,85 * *$ & $2,02 \mathrm{~ns}$ \\
\hline 3. & Berat 1000 butir ( Weight of 1000 seeds) & $31,33 * *$ & $126,54 * *$ & - \\
\hline 4. & Daya berkecambah ( Germination capacity) & $2,32 \mathrm{~ns}$ & $10,26 * *$ & $3,45 *$ \\
\hline
\end{tabular}

Keterangan(Remarks): **=Berpengaruh nyata pada tingkat kepercayaan 99\% (Significant at 99\% confident level)

$*$ = Berpengaruh nyata pada tingkat kepercayaan 95\% (Significant at $95 \%$ confident level) $\mathrm{Ns}=$ Tidak berpengaruh nyata $($ Non significant $)$

Tabel 2 menunjukkan bahwa produksi benih $A$. mangium dari umur 5 - 12 tahun relatif seragam dengan kisaran $(250,07-335,50 \mathrm{~g} /$ pohon). Produksi benih G. arborea dan E. de- glupta cukup beragam dengan kisaran 220 $12.140 \mathrm{~g} /$ pohon (G. arborea) dan 38,59 - 175,79 $\mathrm{g} / \operatorname{pohon}($ E. deglupta).

Tabel (Table) 2. Pengaruh umur pohon terhadap produksi benih A. mangium, G. arborea, dan E. deglupta (The effect of tree ages on production of A. mangium, G. arborea, and $\mathrm{E}$. deglupta seeds)

\begin{tabular}{|c|c|c|c|}
\hline No. & Jenis (Species) & $\begin{array}{c}\text { Umur pohon } \\
\text { (Tree ages) }(\text { tahun/years })\end{array}$ & $\begin{array}{l}\text { Produksi benih per pohon } \\
\text { (Seed production per tree) } \\
\text { (gram) }\end{array}$ \\
\hline 1. & A. mangium & $\begin{array}{c}5 \\
6 \\
7 \\
9 \\
10 \\
11 \\
12\end{array}$ & $\begin{array}{l}250,07 \mathrm{a} \\
312,98 \mathrm{a} \\
313,51 \mathrm{a} \\
325,60 \mathrm{a} \\
335,50 \mathrm{a} \\
311,42 \mathrm{a} \\
253,59 \mathrm{a}\end{array}$ \\
\hline 2. & G. arborea & $\begin{array}{c}7 \\
9 \\
11 \\
13 \\
15 \\
17\end{array}$ & $\begin{array}{rl}3.670 & \mathrm{~b} \\
12.140 & \mathrm{a} \\
9.550 & \mathrm{a} \\
4,280 & \mathrm{~b} \\
230 & \mathrm{c} \\
220 & \mathrm{c}\end{array}$ \\
\hline
\end{tabular}


Tabel (Table) 2. Lanjutan (Continued)

\begin{tabular}{|c|l|c|c|}
\hline No. & Jenis (Species) & $\begin{array}{c}\text { Umur pohon } \\
\text { (Tree ages })(\text { tahun/years })\end{array}$ & $\begin{array}{c}\text { Produksi benih per pohon } \\
\text { (Seed production per tree) } \\
\text { (gram) }\end{array}$ \\
\hline 3. & E. deglupta & 4 & $63,81 \mathrm{~b}$ \\
& & 6 & $38,59 \mathrm{bc}$ \\
& & 8 & $175,79 \mathrm{a}$ \\
& & 10 & $62,65 \mathrm{~b}$ \\
& & 14 & $44,01 \mathrm{~b}$ \\
& & $15,85 \mathrm{c}$ \\
\hline
\end{tabular}

Keterangan (Remarks): Angka-angka yang diikuti oleh huruf yang sama untuk jenis yang sama tidak berbeda nyata pada tingkat kepercayaan 99\% uji Duncan (Values within a similar column and species followed by the same letter are not significantly different in accordance with the results of the 99\% confident level Duncan's multiple range test)

Kecenderungan hubungan antara umur pohon dengan produksi benih G. arborea dan $E$. deglupta dapat dinyatakan dengan persamaan kuadratik sebagai berikut :

$$
\begin{aligned}
& \text { G. Arborea : } \mathrm{Y}=-13,498+4,3364 \mathrm{X} 0,2154 \mathrm{X}^{2} \text {, } \\
& \mathrm{R}^{2}=0,63(\mathrm{r}=0,79) \\
& \text { E. Deglupta : } \mathrm{Y}=-48,3+33,5 \mathrm{X} 1,88 \mathrm{X}^{2}, \mathrm{R}^{2}= \\
& 0,29(r=0,54)
\end{aligned}
$$

dimana $: \mathrm{Y}=$ produksi benih $\operatorname{dan} \mathrm{X}=$ umur pohon.

Berdasarkan regresi di atas, produksi benih $G$. arborea maksimal terjadi pada umur 10 tahun, sedangkan untuk $E$. deglupta, produksi benih maksimalnya terjadi pada umur 9 tahun (Gambar 1 dan 2).

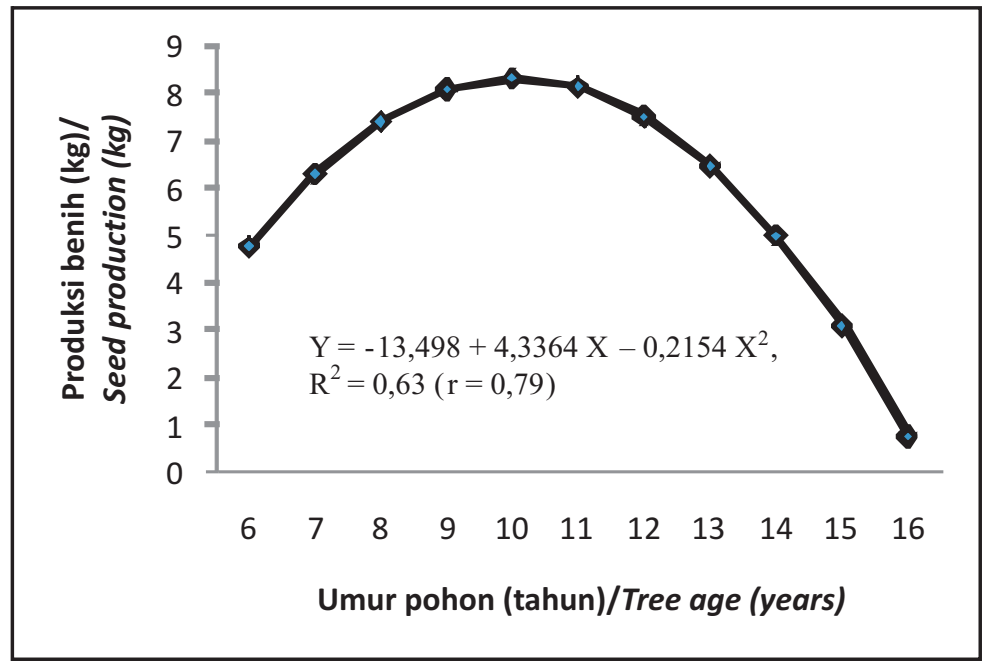

Gambar(Figure)1. Kecenderungan hubungan umur pohon dengan produksi benih G. arborea (Trend of correlation of tree ages with production of $\mathrm{G}$. arborea seeds) 


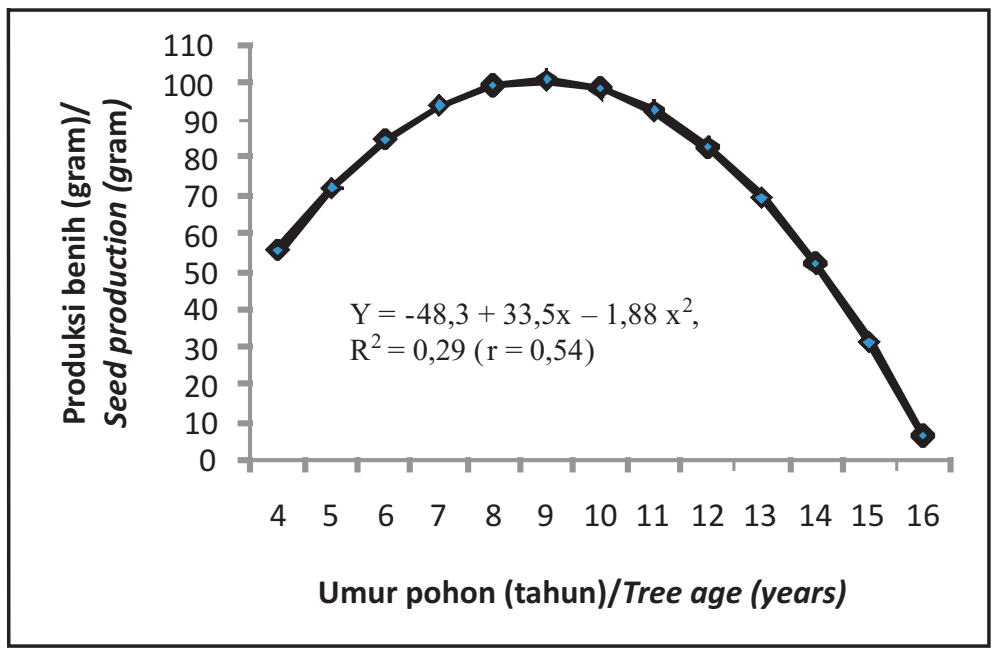

Gambar(Figure) 2. Kecenderungan hubungan umur pohon dengan produksi benih $E$. deglupta (Trend of correlation of tree ages with production of E. deglupta seeds)

Tabel 3 dan 4 memperlihatkan adanya perbedaan mutu fisik benih $A$. mangium dan $G$. arborea (kadar air dan berat 1.000 butir benih), sedangkan pada $E$. deglupta tidak menunjukkan adanya perbedaan kadar air benih antar umur pohon (Tabel 5). Pohon A. mangium yang berumur 5 tahun menghasilkan benih dengan kandungan kadar air yang lebih tinggi, sedangkan untuk berat 1.000 butir benih mempunyai kecenderungan pohon yang berumur lebih muda menghasilkan benih dengan berat yang lebih tinggi. Pada benih G. arborea, kadar air benih pohon yang berumur 7,9 dan 13 tahun yang menghasilkan benih dengan kadar air yang relatif sama $(11,8 \%, 12,0 \%$ dan $12,0 \%)$, sedangkan pohon yang berumur 17 tahun menghasilkan kadar air benih terendah 9,9\% dan tidak berbeda nyata dengan pohon yang berumur 15 tahun (10,1\%). Berat 1.000 butir benih A. mangium cenderung enurun dengan bertambahnya umur pohon, sebaliknya pada $G$. arborea hingga umur 15 tahun berat benihnya cenderung meningkat.

Tabel(Table) 3. Pengaruh umur pohon terhadap mutu benih A. mangium (The effect of tree ages on quality of A. mangium seeds)

\begin{tabular}{|c|c|c|c|c|}
\hline No. & $\begin{array}{c}\text { Umur pohon } \\
\text { (Tree ages }) \\
\text { (tahun/years) }\end{array}$ & $\begin{array}{c}\text { Kadar air } \\
\text { (Moisture content) } \\
(\%)\end{array}$ & $\begin{array}{c}\text { Berat } 1.000 \text { butir } \\
(\text { Weight of } 1.000 \\
\text { seeds) }(\mathrm{gram})\end{array}$ & $\begin{array}{c}\text { Daya berkecambah } \\
\text { (Germination capacity) } \\
(\%)\end{array}$ \\
\hline 1. & 5 & $4,5 \mathrm{a}$ & $1,23 \mathrm{a}$ & $93 \mathrm{a}$ \\
2. & 6 & $3,8 \mathrm{~b}$ & $1,15 \mathrm{a}$ & $90 \mathrm{a}$ \\
3. & 7 & $3,0 \mathrm{c}$ & $1,01 \mathrm{~b}$ & $93 \mathrm{a}$ \\
4. & 9 & $3,7 \mathrm{~b}$ & $0,98 \mathrm{~b}$ & $89 \mathrm{a}$ \\
5. & 10 & $4,3 \mathrm{a}$ & $1,23 \mathrm{a}$ & $90 \mathrm{a}$ \\
6. & 11 & $4,3 \mathrm{a}$ & $0,75 \mathrm{c}$ & $89 \mathrm{a}$ \\
7. & 12 & $3,4 \mathrm{~b}$ & $0,82 \mathrm{c}$ & $92 \mathrm{a}$ \\
\hline
\end{tabular}

Keterangan(Remarks): Angka-angka yang diikuti oleh huruf yang sama pada kolom yang sama tidak berbeda nyata pada tingkat kepercayaan 99\% uji Duncan (Values within a similar column followed by the same letter are not significantly different in accordance with the results of the $99 \%$ confident level Duncan's multiple range test) 
Tabel (Table) 4. Pengaruh umur pohon terhadap mutu benih G. arborea (The effect of tree ages on quality of G. arborea seeds)

\begin{tabular}{|c|c|c|c|c|}
\hline No. & $\begin{array}{c}\text { Umur pohon } \\
\text { (Tree ages }) \\
\text { (tahun/years) }\end{array}$ & $\begin{array}{c}\text { Kadar air } \\
\text { (Moisture content) } \\
(\%)\end{array}$ & $\begin{array}{c}\text { Berat } 1.000 \text { butir } \\
\text { (Weight of } 1.000 \\
\text { seeds) }(\text { gram })\end{array}$ & $\begin{array}{c}\text { Daya berkecambah } \\
\text { (Germination capacity }) \\
(\%)\end{array}$ \\
\hline 1. & 7 & $11,8 \mathrm{a}$ & $46,94 \mathrm{c}$ & $71 \mathrm{~b}$ \\
2. & 9 & $12,0 \mathrm{a}$ & $47,55 \mathrm{c}$ & $76 \mathrm{~b}$ \\
3. & 11 & $11,3 \mathrm{~b}$ & $46,52 \mathrm{c}$ & $82 \mathrm{a}$ \\
4. & 13 & $12,0 \mathrm{a}$ & $46,37 \mathrm{c}$ & $84 \mathrm{a}$ \\
5. & 15 & $10,1 \mathrm{c}$ & $68,37 \mathrm{a}$ & $74 \mathrm{~b}$ \\
6. & 17 & $9,9 \mathrm{c}$ & $58,94 \mathrm{~b}$ & $76 \mathrm{~b}$ \\
\hline
\end{tabular}

Keterangan(Remarks): Angka-angka yang diikuti oleh huruf yang sama pada kolom yang sama tidak berbeda nyata pada tingkat kepercayaan $95 \%$ uji Duncan (Values within a similar column followed by the same letter are not significantly different in accordance with the results of the $95 \%$ confident level Duncan's multiple range test)

Tabel (Table) 5. Pengaruh umur pohon terhadap mutu benih E. deglupta (The effect of tree ages on quality of E. deglupta seeds)

\begin{tabular}{|c|c|c|c|}
\hline No. & $\begin{array}{c}\text { Umur pohon } \\
\text { (Tree ages }) \\
\text { (tahun/years) }\end{array}$ & $\begin{array}{c}\text { Kadar air } \\
\text { (Moisture conten } t) \\
(\%)\end{array}$ & $\begin{array}{c}\text { Daya berkecambah } \\
\text { (Germination capacity) } \\
(\%)\end{array}$ \\
\hline 1. & 4 & $8,8 \mathrm{a}$ & $84 \mathrm{~b}$ \\
2. & 6 & $8,9 \mathrm{a}$ & $86 \mathrm{~b}$ \\
3. & 8 & $9,1 \mathrm{a}$ & $96 \mathrm{a}$ \\
4. & 10 & $9,1 \mathrm{a}$ & $88 \mathrm{ab}$ \\
5. & 14 & $9,2 \mathrm{a}$ & $91 \mathrm{ab}$ \\
6. & 16 & $8,8 \mathrm{a}$ & $96 \mathrm{a}$ \\
\hline
\end{tabular}

Keterangan(Remarks): Angka-angka yang diikuti oleh huruf yang sama pada kolom yang sama tidak berbeda nyata pada tingkat kepercayaan 99\% uji Duncan (Values within a similar column followed by the same letter are not significantly different in accordance with the results of the $99 \%$ confident level Duncan's multiple range test)

Umur pohon tidak memberikan perbedaan yang nyata pada daya berkecambah benih $A$. mangium, sebaliknya untuk benih $G$. arborea dan $E$. deglupta terdapat perbedaan nyata pengaruh umur pohon terhadap daya berkecambah benihnya. Kecenderungan hubungan antara umur pohon dengan daya berkecambah benih $G$. arborea dan E. deglupta dapat dinyatakan dengan persamaan kuadratik sebagai berikut:

$$
\begin{gathered}
\text { G. Arborea : } \mathrm{Y}=39,30+8,49 \mathrm{X} \quad 0,366 \mathrm{X}^{2}, \mathrm{R}^{2} \\
=0,16(\mathrm{r}=0,43)
\end{gathered}
$$

$$
\begin{aligned}
& \text { E. Deglupta : } \mathrm{Y}=79,4648+1,7459 \mathrm{X} \quad 0,0520 \\
& X^{2}, R^{2}=0,44(r=0,66)
\end{aligned}
$$

dimana: $\mathrm{Y}=$ daya berkecambah dan $\mathrm{X}=$ umur pohon E. deglupta.

Berdasarkan regresi di atas, daya berkecambah maksimal benih $G$. arborea terjadi pada umur 11 tahun, sedangkan untuk $E$. deglupta, daya berkecambah maksimalnya terjadi pada umur 16 tahun (Gambar 3 dan 4). 


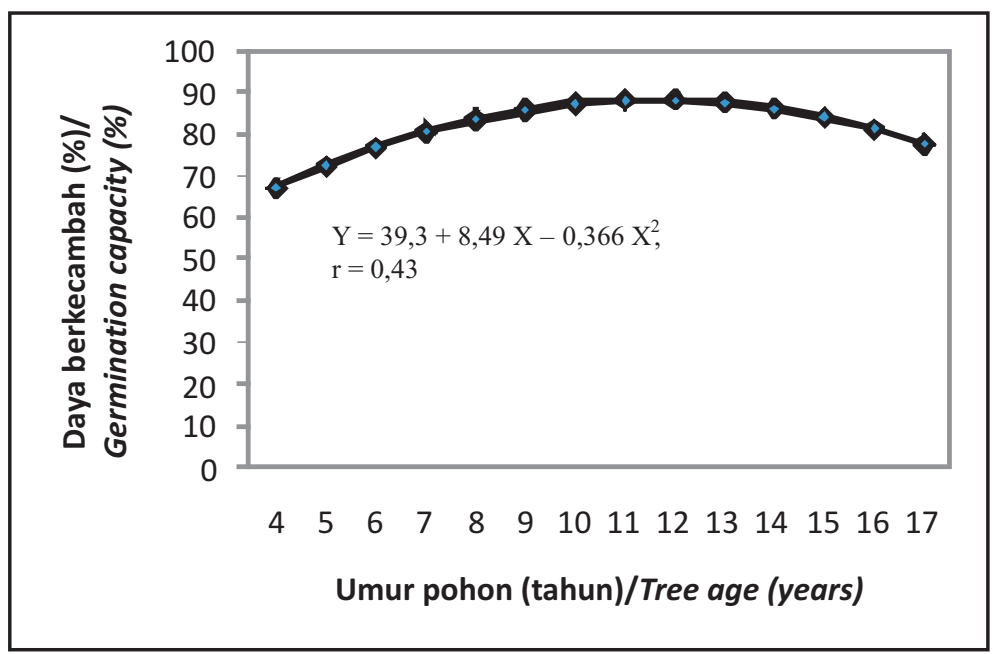

Gambar(Figure) 3. Hubungan umur pohon dengan daya berkecambah benih G. arborea (The correlation between tree ages with germination capacity of G. arborea seeds)

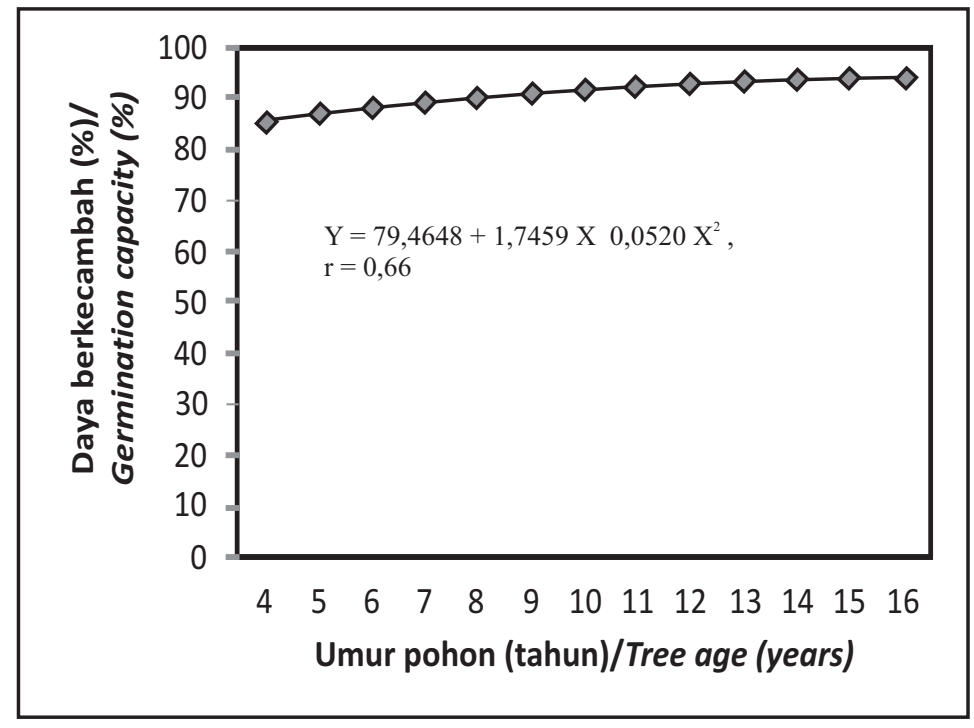

Gambar(Figure) 4. Hubungan umur pohon dengan daya berkecambah benih E. deglupta (The correlation between tree ages with germination capacity of E. deglupta seeds)

\section{B. Pembahasan}

Produksi benih dan daya berkecambah benih A. mangium selama pohon berumur 5 - 12 tahun tidak berbeda nyata dengan kisaran produksi 250,07 - 335,50 g/pohon, sementara walaupun korelasi produksi benih dan daya berkecambah $G$. arborea dan E. deglupta terhadap umur pohon rendah (berturut-turut $63 \%$ dan 18\%; 29\% dan 44\%), namun berdasarkan uji beda nyata antara umur pohon dengan daya berkecambahnya terlihat berbeda nyata pada $G$. arborea umur 11 dan 13 tahun sedangkan pada $E$. deglupta umur di atas 8 tahun.

Kisaran produksi benih $G$. arborea adalah $0,2212,14 \mathrm{~kg} /$ pohon dengan produksi maksimal terjadi pada umur 10 tahun, sedangkan untuk $E$. deglupta, kisaran produksi benihnya adalah 38,59 - 175,79 g/pohon dengan produksi maksimal terjadi pada umur 9 tahun. Sejalan 
dengan pertambahan umur pohon maka jarak tanam yang berukuran $3 \times 3 \mathrm{~m}$ merupakan ruang tumbuh yang kurang memadai untuk perkembangan munculnya bunga dan buah yang diperlukan setiap jenis pohon. Peningkatan kerapatan pohon akibat tidak adanya penjarangan seleksi, sehingga tajuk-tajuk pohon saling bersentuhan, sehingga hanya bagian atas tajuk saja yang dapat menerima sinar matahari langsung dan melakukan pembungaan dan pembuahan.

Keterbukaan tajuk yang baik akan menghasilkan permukaan fotosintesis yang makin luas. Bila cahaya matahari yang diterima tajuk makin banyak, maka proses fotosistesis akan lebih tinggi sehingga karbohidrat yang dihasilkan akan makin banyak. Kandungan karbohidrat yang tinggi akan merangsang pertumbuhan generatif yang ditandai dengan munculnya bunga dan buah. Pohon yang mengalami persaingan hebat dan jelek pertumbuhannya akan menghasilkan benih sedikit Manan (1976). Selain faktor tersebut di atas, persaingan unsur hara juga terjadi lebih tinggi dengan bertambahnya volume pohon. Daya dukung hara tanah sudah tidak mampu lagi mencukupi kebutuhan optimal setiap pohon yang tumbuh rapat sehingga proses pembungaan dan pembuahan pun kurang optimal sehingga pada umur 11 tahun untuk $G$. arborea dan 10 tahun untuk E. deglupta terjadi kecenderungan penurunan produksi benih.

Penelitian lainnya terhadap E. deglupta dilakukan oleh Mindawati (1992) yang melaporkan bahwa perbedaan umur pohon $(2,3,4,5,6,7$, dan 8 tahun) memberikan pengaruh yang nyata terhadap produksi buah. Umur pohon 7 tahun merupakan umur yang memberikan produksi benih tertinggi. Bentuk tajuk yang baik dan terbuka dapat dihasilkan dari tindakan penjarangan seleksi yang tepat sehingga tegakan tersebut mampu memproduksi benih dengan optimal. Penjarangan seleksi selain akan mengurangi persaingan antar pohon dan memperbaiki bentuk tajuk. Dilihat dari mutu fisiologinya, umur pohon $A$. mangium tidak memberikan pengaruh yang nyata terhadap daya berkecambah benih yang dihasilkannya. Dengan demikian, daya berkecambah benih $A$. mangium yang dihasilkan pada beberapa tingkat umur pohon relatif seragam. Secara fisiologi, pengunduhan benih dari pohon-pohon berumur 5 tahun sampai 12 tahun masih mempunyai mutu yang baik, hal ini digambarkan dengan daya berkecambahnya yang relatif tinggi $(>89 \%)$.
Perbedaan umur pada pohon induk $G$. arborea menghasilkan benih dengan mutu fisik yang berbeda nyata dengan kadar air benih. Pohon yang berumur 7, 9 dan 13 tahun relatif sama $(11,8 \%, 12,0 \%$ dan $12,0 \%)$, sedangkan pohon yang berumur 17 tahun menghasilkan kadar air benih terendah 9,9\% dan tidak berbeda nyata dengan pohon yang berumur 15 tahun $(10,1 \%)$. Dari data tersebut diperoleh gambaran bahwa pohon yang lebih tua, kadar air benihnya mempunyai kecenderungan lebih rendah. Sedangkan untuk berat 1.000 benih terdapat kecenderungan mulai meningkat pada umur 9 tahun dan mengalami penurunan setelah umur 15 tahun.

Mutu fisiologi benih G. arborea 11 - 13 tahun cukup baik, hal ini tercermin dari daya berkecambahnya yang tinggi ( $82 \%$ dan $84 \%$ ), sedangkan daya berkecambah pada umur 7, 9, 15 dan 17 tahun sekitar 71\%. Dengan demikian umur optimal (umur pertengahan) untuk jenis $G$. arborea untuk efisensi pengunduhan dan penanaman adalah umur $11-13$ tahun di Kenangan, PT. ITCI Hutani Manunggal, Kalimantan Timur Beberapa penelitian lainnya menunjukkan adanya korelasi antara umur pertengahan (middle age) dengan karakteristik benih, seperti berat 1000 butir, produksi, dan perkecambahan benih pada jenis Pinus echinata (Grayson et al., 2002 dalam Espahbodi et al., 2007) dan Sorbus torminalis (Espahbodi et al., 2007).

Umur pohon E. deglupta tidak memberikan hasil yang berbeda nyata terhadap mutu fisik benih (kadar air benih), namun menghasilkan daya berkecambah yang berbeda nyata. Daya berkecambah $E$. deglupta meningkat mulai umur 9 tahun dan mencapai maksimalnya pada umur 16 tahun. Hasil penelitian ini sejalan dengan penelitian yang dilakukan oleh Mindawati (1992) terhadap E. deglupta yaitu umur pohon tidak berpengaruh nyata terbadap daya berkecambah benih. Dengan demikian, pengunduhan benih untuk upaya penanaman berskala besar dapat dilakukan pada tegakan E. deglupta sejak umur 9 tahun.

Raja et al. (2004) juga menyatakan bahwa pohon yang berumur muda dapat menghasilkan benih yang viabel tetapi persentase benih hampanya tinggi atau mempunyai vigor rendah, kecuali bila terjadi penyerbukan silang dari pohon yang lebih tua. Pohon-pohon yang masih muda hanya sedikit menghasilkan serbuk sari dan penyerbukannya kurang memadai. Dengan 
demikian umur optimal suatu tegakan untuk dikumpulkan benihnya perlu diketahui sehingga diperoleh benih dengan jumlah dan mutu yang memadai.

\section{KESIMPULAN}

1. Produksi dan daya berkecambah benih pohon A. mangium tidak berkorelasi nyata dengan umur pohon. Kisaran produksi benih tiap umur pohon relatif seragam $(250,07$ 335,50 gram/musim).

2. Pengunduhan benih efektif dapat dilakukan pada tegakan $G$. arborea sejak pohon berumur 9 tahun dengan produksi oprimal pada umur 11 - 13 tahun.

3. Produksi dan daya berkecambah benih $E$. deglupta meningkat sejalan dengan peningkatan umur pohon yaitu sejak pohon berumur 8 - 16 tahun.

\section{DAFTAR PUSTAKA}

Alrasjid, H., D. Natawiria, dan A.N. Ginting. 1983. Pembinaan Hutan Pinus khususnya Pinus merkusii sebagai Penghara Industri. Makalah Simposium Pengusahaan Hutan Pinus. Manggala Wana Bakti. Jakarta.

Apif, M. 2002. Strategi Pengembangan Industri Pulp Berbasis Hutan Tanaman Industri Pulp pada Kawasan Sentra Produksi di Propinsi Riau. Tesis Program Pasca Sarjana Manajemen dan Bisnis Institut Pertanian Bogor. Bogor.

BTP (Balai Teknologi Perbenihan). 2000. Pedoman Standarisasi Uji Mutu Fisik dan Fisiologis Benih Tanaman Hutan. Publikasi Khusus. Balai Litbang Teknologi Perbenihan. Bogor.

Daniel, T.W., J.A. Helm, dan F.S. Baker. 1987. Prinsip-prinsip Silvikultur (terjemahan). Gajah Mada University Press. Yogyakarta.

Departemen Kehutanan. 2009. Statistik Kehutanan Indonesia 2008. Departemen Kehutanan. Jakarta.

DPTH (Direktorat Perbenihan Tanaman Hutan). 2008. Pedoman Perhitungan Potensi Produksi Sumber Benih. Direktorat Perbenihan Tanaman Hutan. Direktorat
Jenderal Rehabilitasi Lahan dan Perhutanan Sosial. Jakarta.

Espahbodi, K., S. M. Hosseini, H. MirzaieNodoushan, M. Tabari, M. Akbarinia, and Y. Dehghan-Shooraki. 2007. Tree Age Effects on Seed Germination in Sorbus torminalis. Gen. Appl. Plant Physiology $33(1-2): 107-119$.

ISTA (International Seed Testing Association). 2006. International Rules for Seed Testing, Rules Edition 2006. The International Seed Testing Association. Bassersdorf. CH-Switzerland.

ISTA (International Seed Testing Association). 2010. International Rules for Seed Testing Edition 2010. The International Seed Testing Association. Bassersdorf. CHSwitzerland.

Manan, S. 1976. Silvikultur. Proyek Pengembangan dan Peningkatan Perguruan Tinggi. IPB. Bogor.

Mindawati, N. 1992. Pengaruh Umur Pohon terhadap Produksi dan Perkecambahan Benih Eucalyptus deglupta. Buletin Penelitian Hutan No. 552. Badan Penelitian dan Pengembangan Hutan. Bogor.

Mindawati, N., T. Rostiwati. dan N. Rochayat. 1991. Studi pendugaan produksi buah Eucalyptus deglupta di Balai Teknologi Reboisasi, Benakat. Buletin Penelitian Hutan. ,No. 535

Owens, J.N. 1995. Constraints to Seed Production : Temperate and Tropical Forest Trees. Tree Physiology. Heron Publishing. Canada. pp.477-484.

Pillai, R.V. 1994. Coconut Seed Production. In: Advances in Horticulture, Vol.10. Plantation and Spice Crops Part 2 (Chadha, K.L. and Rethinam, P., Eds.). Malhotra Publishing House, New Delhi. pp. 655670.

Ponnusamy, A.S. 1993. Seed Technological Studies in Neem (Azadirachta indica A. Juss). Ph.D. Thesis, Tamil Nadu Agricultrual University, Coimbatore.

Poulsen, K.M. 1994. Seed Testing. Lecture Note No. C-8, July 1994. Danida Forest Seed Centre. DK-3050 Humlebaek. Denmark. 
Raja, K., V. Palanisamy, and P. Selvaraju. 2004. Effect of Palm Age on Seed Germination and Seedling Vigour in Arecanut (Areca catechu L.). Research Notes. Madras Agriculture Jurnal 91(4-6):326-328.

Soekotjo, W. 1984. Silvika. Departemen Manajemen Kehutanan. Fakultas Kehutanan IPB. Bogor
Stubsgaard, F. and J. Baadsgaard. 1994. Planning Seed Collections. Indonesia Tree Seed Source Development Project. Ministry of Forestry. Jakarta. 